\title{
The Stability of Sulfide Sorbents Based on Silica in Aqueous Media. Part II. MCM-41 Matrix
}

\author{
Svetlana A. Kozlova*a, Yulia N. Zaitseva ${ }^{a}$, \\ Vladimir A. Parfenov ${ }^{\mathrm{a}}$ and Aleksandr S. Samoilo ${ }^{\mathrm{b}}$ \\ anstitute of Chemistry and Chemical Technology SB RAS \\ FRC "Krasnoyarsk Science Center SB RAS" \\ 50/24 Akademgorodok, Krasnoyarsk, 660036, Russia \\ ${ }^{b}$ Siberian Federal University \\ 79 Svobodny, Krasnoyarsk, 660041, Russia
}

Received 23.01.2017, received in revised form 20.04.2017, accepted 27.09.2017

\begin{abstract}
Sulfide sorbents based on MCM-41 have been synthesized. The chemical and thermal stability of the sorbents obtained has been investigated by physicochemical methods. It has been found that the acid treatment of the samples at the boiling point results in insignificant changes in structural, textural and sorption characteristics, demonstrating the total losses of the sorbent up to $15 \mathrm{wt} \%$, which is considered to be connected with the dissolution of the malformed and unstructured particles of a silica matrix. The neutral and alkaline treatment induces more significant changes associated with the starting matrix dissolution (the weight loss is about 25-30 wt\%). Nevertheless, the grafted organic functional layer is retained. The sorbents obtained are quite stable in the studied aggressive conditions and able to work over a long period of time in a variety of technological solutions and are not inferior to the well-known commercial sorbents with functional groups.
\end{abstract}

Keywords: mesoporous mesostructured silica, MCM-41, grafting, stability, treatment, sorption, palladium.

Citation: Kozlova S.A., Zaitseva Yu.N., Parfenov V.A., Samoilo A.S. The stability of sulfide sorbents based on silica in aqueous media. Part II. MCM-41 matrix, J. Sib. Fed. Univ. Chem., 2018, 11(1), 31-41. DOI: 10.17516/1998-2836-0056.

(C) Siberian Federal University. All rights reserved

* Corresponding author E-mail address: sakozlova@gmail.com 


\title{
Стабильность сульфидных сорбентов \\ на основе оксида кремния в водных средах. \\ Часть 2. Носитель МСМ-41
}

\author{
С.А. Козлова ${ }^{a}$ Ю.Н. Зайцева ${ }^{a}$, \\ В.А. Парфенов ${ }^{a}$, А.С. Самойло \\ ${ }^{a}$ Институт химии и химической технологии СО РАН \\ ФИЦ "Красноярский научный иентр СО РАН" \\ Россия, 660036, Красноярск, Академгородок, 50/24 \\ ${ }^{6}$ Сибирский федеральный университет \\ Россия, 660041, Красноярск, пр. Свободньй, 79
}

Синтезированы сульфидные сорбенты на основе МСM-41, исследована их химическая и термическая стабильность различными физико-химическими методами. Обнаружено, что кислотная обработка образцов при температуре кипения приводит к незначительным изменениям структурных, текстурных и сорбиионных характеристик, демонстрируя общие потери сорбента до 15 масс.\%. Указанный факт связан с растворением плохо сформированных и неструктурированных частии кремниевой матрицы. Нейтральная и щелочная обработка приводит $к$ более значительным изменениям, связанным с растворением исходной матрицы (потеря массы составляет около 25-30 масс.\%). Тем не менее привитый органический функииональный слой сохраняется. Полученные сорбентын на основе MCM-41, как и на основе SBA-15, относительно стабильны в изученных агрессивных условиях и способны работать в течение длительного периода времени в различных технологических растворах.

Ключевые слова: мезопористый мезоструктурированный диоксид кремния, МСМ-41, прививка, сульфидный сорбент, стабильность, обработка, сорбиия, палладий.

\section{Introduction}

The discovery of mesostructured mesoporous materials in the early 1990s [1] supported the studies in many fields of chemistry [1,2]. Narrow-pore size distribution, high specific surface area and pore volume make periodic mesoporous silicas promising supports for metal sorbents. Two most common types of periodic silicas include MCM-41, MCM-48 and SBA-15 materials. MCM-41 materials [1] are generally synthesized in a basic medium in the presence of surfactant cations. The pore diameter of the MCM-41 materials usually vary from 20 to $100 \AA$ as a function of the alkyl chain length of the surfactant template and synthesis conditions. The solid has periodically ordered structures, which consist of two dimensional hexagonal arrays of uniform mesopores.

In recent years a great number of scientific papers on the stability of mesoporous materials have been published [3-7]. The stability of the MCM-41 silica matrix in various aqueous solutions of acids and alkalines was studied [3, 4, 7]. The limited hydrothermal stability is considered as one of the weaknesses of MCM-41 associated with thermal treatment in water or steam, or both, which was 
described by Kim and Ryoo [7], where MCM-41 and MCM-48 are reported to disintegrate in water at temperatures above $343 \mathrm{~K}$; the disappearance of the ordered features was ascribed to hydrolysis and collapse of the structure due to the ill-crystallized thin walls. The effect proved to be irreversible, which was observed even at room temperature in wet saturated atmospheres $[8,9]$.

Cassiers et al. [10] presented a systematic study of various types of relevant ordered mesoporous materials under steam; it was found that MCM-41 is a less stable structure under the applied conditions; 30 vol $\% \mathrm{H}_{2} \mathrm{O}$ at $400{ }^{\circ} \mathrm{C}$ for 48 and $120 \mathrm{~h}$. In [4] the authors published the results concerning the test of SBA-1, SBA-3, SBA-15, MCM-41, MCM48 materials in acidic media $(\mathrm{HCl}$, $\mathrm{H}_{2} \mathrm{SO}_{4}, \mathrm{H}_{3} \mathrm{PO}_{4}$ ). They described the mechanism of changes in mesoporous materials occurring according to the following scheme: the micropores were first damaged by the acidic stress, and then the mesopores were partially collapsed or partially blocked. There, the authors found that the material resistance to acidic media is connected with the critical wall thickness and pore diameter threshold.

The authors [11] against observed relatively high stability of the SBA-15 mesoporous lattice during impregnation with aqueous solutions of cobalt nitrate; drying and calcination makes this material a potentially good support for metal and oxide heterogeneous catalysts. We carried out a study [3] where it was shown that the MCM-41 matrix was subjected to insignificant dissolution with the weight loss in the media used. Nevertheless, it retains the highly ordered mesostructured structure. There, the mechanism of the fragmentary material disintegration based on the MCM-41 molecular model and interpretation of the percolation theory were proposed. There are also a great number of publications [12-17] on the methods to increase the hydrothermal stability of these MCM-41 type materials. At present the hydrothermal stability of the silica-based MCM-41 type materials has already a high level comparable to microporous zeolites.

In [18] the peculiarities of the sulfide sorbent synthesis on the MCM-41 and SBA-15 matrices were described. The results showed them to be good metal sorbents. However, to fully understand the capabilities of these materials as sorbents there is no evidence on the technological characteristics of the materials obtained, in particular, concerning their stability. As a result, there originated an idea to study its chemical and thermal stability. The present paper is the second part of the stability study of the sorbents based on novel mesoporous materials. In our recent publication [19] the high chemical and thermal stability of the sulfide sorbent based on SBA-15 under the influence of various aqueous media at the boiling temperature was shown.

Thus, the objectives of the current work are to synthesize a sorbent based on MCM-41 with sulfide functional groups, and to investigate its physicochemical characteristics and stability in aqueous media at the boiling point.

\section{Experimental part}

The following reagents were used: tetraethoxysilane (TEOS), reagent-grade; rectified alcohol (EtOH), cetyltrimethylammonium bromide (CTABr): $\mathrm{C}_{16} \mathrm{H}_{33}\left(\mathrm{CH}_{3} \mathrm{O}\right)_{3} \mathrm{NBr}$ (Sigma Aldrich, Cat.: 855820); aqueous ammonia, reagent-grade; 3-glycidoxypropyltrimethoxysilane (GPTMS): $\mathrm{C}_{9} \mathrm{H}_{20} \mathrm{O}_{5} \mathrm{Si}$ (Sigma Aldrich, Cat.: 440167); thiophenol (TPh): (Sigma Aldrich, Cat.: 89021); anhydrous methanol; sodium metal; toluene, chemically pure; hydrochloric acid, reagent-grade; nitric acid, reagent-grade; and sulfuric acid, reagent-grade. 
The synthesis of MCM-41 sorbent

The MCM-41 silica was synthesized using the procedure described earlier [20], the reagent molar ratio being:

1 TEOS : 0.2 CTABr : $22 \mathrm{NH}_{3 \text { aq }}: 52 \mathrm{EtOH}: 475 \mathrm{H}_{2} \mathrm{O}$.

About $3.98 \mathrm{~g}$ of CTABr were dissolved in an aqueous-alcoholic solution $\left(400 \mathrm{ml}\right.$ of $\mathrm{H}_{2} \mathrm{O}$ and $168 \mathrm{ml}$ of EtOH) at room temperature with intensive mixing. With the dissolving being completed, $89 \mathrm{ml}$ of ammonia solution ( $\mathrm{pH} 12.5$ ) were added. Then, $11.5 \mathrm{~g}$ of TEOS were slowly added. The solution was mixed for $2 \mathrm{~h}$. Thereafter, hydrothermal treatment was performed at $120{ }^{\circ} \mathrm{C}$ for $2 \mathrm{~h}$. The precipitate obtained was filtered, washed with water and dried in air at room temperature. Calcination in air at $550{ }^{\circ} \mathrm{C}$ for $3 \mathrm{~h}$ was carried out to remove the organic template from the sample.

The sorbent was synthesized according to the technique described in the patent [21] in two steps. Thiophenol (TPh) was attached to the MCM-41 surface over 3-glycidoxypropyltrimenthoxysilane (GPTMS). $2 \mathrm{~g}$ of $T P h$ were dissolved in $10 \mathrm{ml}$ of dry methanol, where $0.2 \mathrm{~g}$ of metallic sodium were previously dissolved. This mixture was slowly added to a round-bottom flask with two necks, equipped with a thermometer, a reflux condenser and a calcium chloride tube containing $20 \mathrm{ml}$ of dehydrated toluene and $4.3 \mathrm{~g}$ of GPTMS at $75{ }^{\circ} \mathrm{C}$. The synthesis of 3-(2-hydroxy-3phenylsulfanilpropoxy)propyltrimethoxysilane (HPSTMS) was carried out for 12-14 hours using magnetic stirrer heating at a temperature not higher than $75{ }^{\circ} \mathrm{C}$ according to the following reaction:

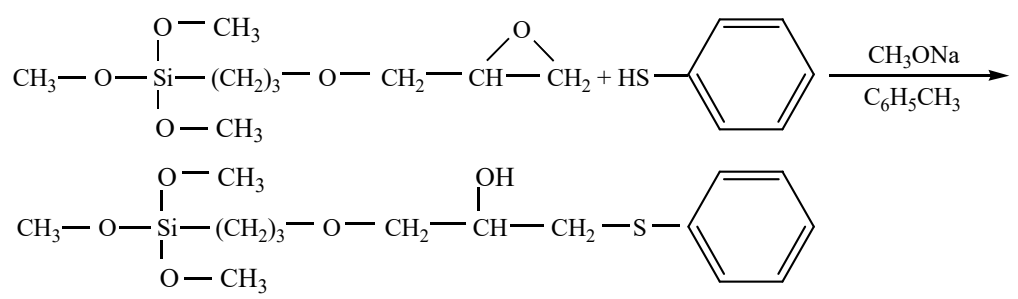

The chemical modification of the support was performed with HPSTMS according to the following reaction (simple immobilization):

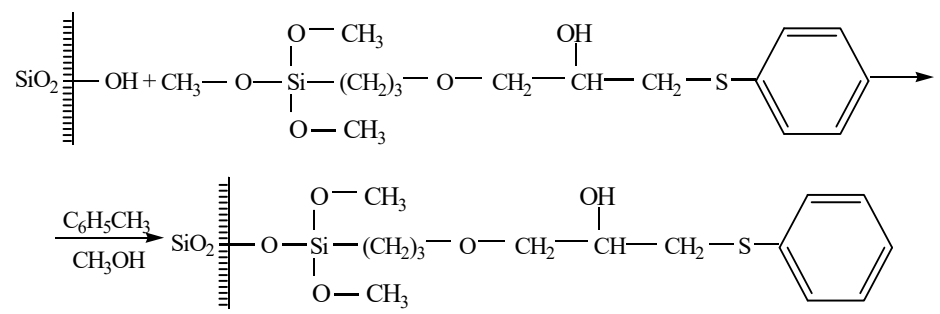

A half amount of HPSTMS was added to $1 \mathrm{~g}$ support $\left(\mathrm{MCM}-41 \mathrm{~S}_{\mathrm{sp}} \sim 1100 \mathrm{~m}^{2} / \mathrm{g}\right.$ ). Then, $10 \mathrm{ml}$ of absolute toluene was added to the resulting suspension. The mixture was heated to $68-70{ }^{\circ} \mathrm{C}$ overnight using the magnetic stirrer. The resulting product was separated with the Shott funnel $\rightarrow$ glass filter using a vacuum pump. The precipitate was carefully washed with toluene and hot ethanol. The resulting sorbent "M-Sorb" was dried in air at room temperature. 


\section{The sorbent treatment}

The experiment included the chemical treatment of the mesoporous silica MCM-41 with the grafted sulfide functional groups. The M-Sorb sample was divided into five parts (samples). These samples were exposed to different aqueous media, such as water, hydrochloric acid, nitric acid, sulfuric acid, and ammonia at the boiling temperature. To treat the samples, $300 \mathrm{mg}$ of the M-Sorb sample were added to the chemical agent into bottom flask. The solid/liquid ratio was equal to 1:100. Then, the suspension was heated to $100{ }^{\circ} \mathrm{C}$ and boiled for $1 \mathrm{~h}$. Table 1 shows the detailed conditions for the sample treatment.

After boiling, the sample was filtered and washed with distilled water. Then, the solid residue was dried in vacuum at $80^{\circ} \mathrm{C}$ for $6 \mathrm{~h}$. The samples obtained were studied by X-ray diffraction, lowtemperature nitrogen adsorption, IR-spectroscopy, thermal analysis, X-ray fluorescence and palladium sorption.

\section{Methods of sample characterization}

The X-ray patterns were taken using $\mathrm{Cu} \mathrm{K} \alpha$-radiation with the diffractometer X'Pert PRO (PANalytical ${ }^{\circledR}$, Netherlands) with the PIXcel detector, equipped with a graphite monochromator. The diffraction measurements were registered within the angular range $2 \Theta 0.40-7.04^{\circ}$, the step being $0.026^{\circ}$ and accumulation time $-120 \mathrm{~s}$ at each point.

The nitrogen adsorption-desorption isotherms were obtained using the volumetric adsorption system ASAP 2420 (Micromeritics ${ }^{\circledR}$, USA) at $\mathrm{T}=77 \mathrm{~K}$ in the range of differential pressures $\left(\mathrm{P} / \mathrm{P}_{\mathrm{o}}\right) 0.06$ 0.99 with the step being 0.015 . The specific surface area was calculated using the BET model [22] in the range of $\left(\mathrm{p} / \mathrm{p}_{\mathrm{o}}\right)$ 0.06-0.25, and pore distribution according to the size - using the $B J H$ and $K J S$ isotherm equation $[23,24]$.

The IR-spectra were recorded using the IR-spectrometer "Tensor 27" (Bruker ${ }^{\circledR}$, Germany) (at the Center of Collective Use of KSC SB RAS) within the range of 500-4000 $\mathrm{cm}^{-1}$ using the standard technique of sample tableting with $\mathrm{KBr}$ (weight ratio of sample $/ \mathrm{KBr}=1: 1000$ ). The sample $/ \mathrm{KBr}$ ratio was equal to 1:400. The sample weight was $1 \mathrm{mg}$.

The thermal analysis (TA) of the samples was made in platinum crucibles using the thermal analyzer SDT Q600 (TA Instruments ${ }^{\circledR}$, USA). Before the analysis the samples were kept in a desiccator at a temperature of $23{ }^{\circ} \mathrm{C}$ and air humidity of $30 \%$. The sample weight was equal to $5 \mathrm{mg}$, the scanning range being $40-900{ }^{\circ} \mathrm{C}$, with the heating rate of $20^{\circ} \mathrm{C} / \mathrm{min}$.

Table 1. The conditions of sample treatment. The treatment time $-1 \mathrm{~h}$, the treatment temperature $-100{ }^{\circ} \mathrm{C}$

\begin{tabular}{|c|c|c|c|}
\hline № & Sample & Chemical agent & Weight loss(\%) \\
\hline 1 & $\mathrm{M}-\mathrm{HCl}$ & $1 \mathrm{M} \mathrm{HCl}$ & 14 \\
\hline 2 & $\mathrm{M}-\mathrm{HNO}_{3}$ & $1 \mathrm{MHNO}_{3}$ & 14 \\
\hline 3 & $\mathrm{M}-\mathrm{H}_{2} \mathrm{SO}_{4}$ & $1 \mathrm{M} \mathrm{H}_{2} \mathrm{SO}_{4}$ & 14 \\
\hline 4 & $\mathrm{M}-\mathrm{H}_{2} \mathrm{O}$ & $\mathrm{H}_{2} \mathrm{O}$ & 24 \\
\hline 5 & $\mathrm{M}-\mathrm{NH}_{3 \mathrm{aq}}$ & $0.1 \mathrm{MNH}_{3 \mathrm{aq}}$ & 34 \\
\hline
\end{tabular}


The sulfur and palladium content was determined by X-ray fluorescence (XRF), using a spectrometer "Axios Advanced" (PANalytical ${ }^{\circledR}$, Netherlands). The spectra within the wavelength range of the periodic table were recorded, and the semi-quantitative analysis of the element content was performed using the program $\mathrm{IQ}^{+}$.

The palladium (II) sorption was carried out from the chloride solution under static conditions. $50 \mathrm{mg}$ of the sorbent were placed into a $50 \mathrm{ml}$ conic flask with a rubber plug. $10 \mathrm{ml}$ of the solution containing palladium $11 \mathrm{mmol} / 1$ in $0.1 \mathrm{M} \mathrm{HCl}$ in the flask were added. The contact time between the solution and the sorbent sample was 24 hours with the constant stirring using a laboratory shaker at a stirring rate of $170 \mathrm{rpm}$. After the separation (using "a blue ribbon" filter) the solid residue was washed with distilled water and dried in air at room temperature. Then, the palladium and sulfur contents of the dry sorbent were determined by X-ray fluorescence.

\section{Results and discussion}

The current investigation is directed to the study of three physicochemical characteristics, namely, the pore structure, the grafted layer and the sorption ability. Also, in the course of the experiments the sample weight was controlled. Table 1 shows that the sorbent treatment under rigid conditions results in the weight loss of the samples. The weight loss is especially significant in the case of using more alkaline media: water and ammonia. After the acidic treatment the sample weight loss was $14 \%$, and after the treatment with water and ammonia it amounted to 24 and $34 \mathrm{wt} \%$, correspondingly. The weight loss after the treatment is likely to be associated with the partial dissolution of the silica matrix, partial washing-out of the grafted functional layer, and the sample loss during the treatment procedure (decantation, filtration etc.).

The X-ray results are not given here because the X-ray patterns do not reveal the porous structure of the material as a consequence of the full pore-filling after grafting. The isotherms of lowtemperature nitrogen adsorption and pore size distribution are presented in Fig. 1. The MCM-41 matrix is characterized by the IV-type isotherm according to the IUPAC classification, but after grafting the isotherm is becoming a nearly straight line, indicating the surface absence. The acidic treatment hardly changes the form of the isotherm, while the treatment with water and ammonia results in more significant consequences.

The pore size distribution is shown for the adsorptive area of the isotherm, that gives a more reliable distribution in the presence of hysteresis (Fig. 1b). A more detailed consideration of the nitrogen adsorption data shows that after grafting (the M-Sorb sample) the surface area dramatically falls from 1023 to $9 \mathrm{~m}^{2} / \mathrm{g}$ as well as the pore volume - from 1.11 to $0.04 \mathrm{~cm}^{3} / \mathrm{g}$. In this case, the pore diameter is too small to be determined. As is shown in Table 2 the acidic treatment expands the pore diameter up to $25 \AA$. The treatment with water and ammonia expands the pore diameter only up to $19 \AA$ and influences the silica matrix rather than the grafted organic matter. The treatment using ammonia, as is shown in Fig. 1, affects the silica framework and shifts the pore volume maximum till disappearance. The liberation of the sample surface treated in the acidic media is likely to occur due to the dissolution of small malformed silica particles in the pores. Their dissolution explains the weight loss of the samples, and increase in the specific surface and pore volume (Table 1 and 2).

The functional groups contained in the samples were identified using IR-spectroscopy. The results showed that after grafting the changes take place in three main wavenumber ranges. 2930-

$$
-36-
$$



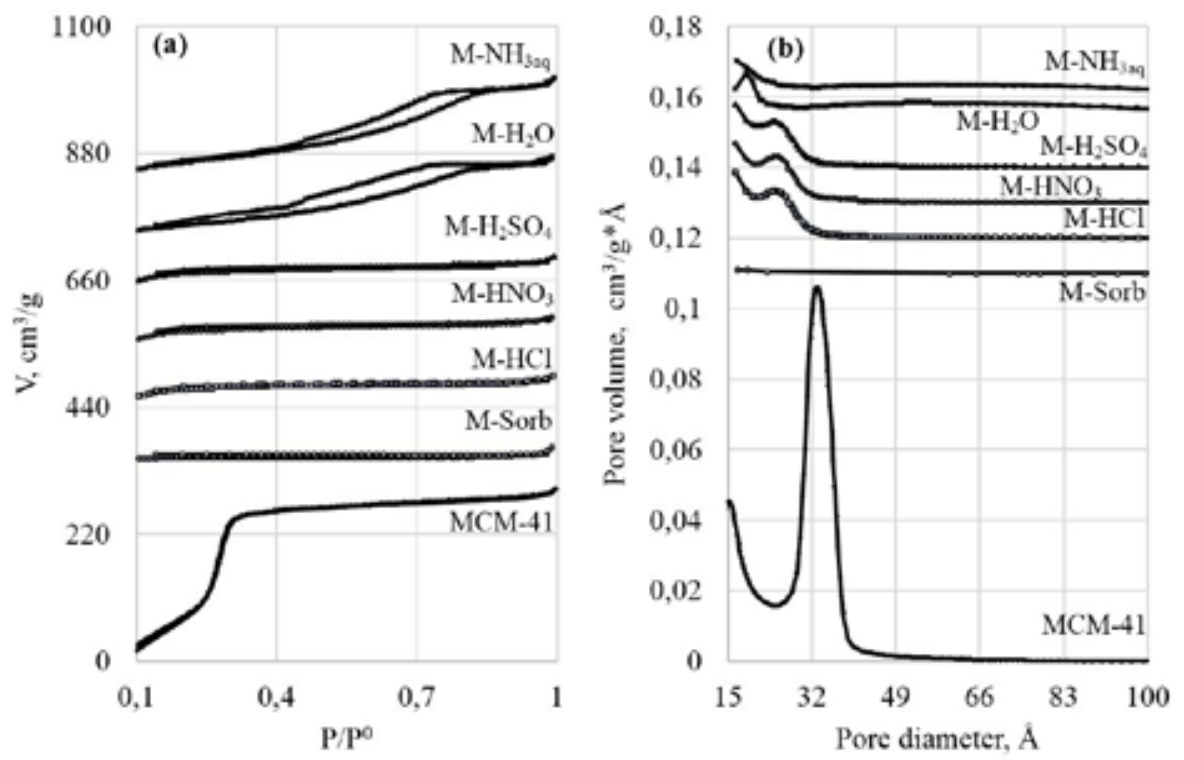

Fig. 1. The nitrogen low-temperature adsorption isoterms (a) and the pore size distribution plots (b) for the samples of original MCM-41 and sorbent (M-Sorb) before and after treatment in different aqueous media. The isoterms are shifted along Y-axis from each other for $\sim 100 \mathrm{~cm}^{3} / \mathrm{g}$ and pore size distribution plots - for $\sim 0,25$ units

Table 2. The textural characteristics of MCM-41 sorbent samples

\begin{tabular}{|c|c|c|c|c|}
\hline № & Sample & $\mathrm{S}_{\mathrm{BET}}\left(\mathrm{m}^{2} / \mathrm{g}\right)^{\mathrm{a}}$ & $\mathrm{V}_{\text {BJH }}\left(\mathrm{cm}^{3} / \mathrm{g}\right)^{\mathrm{b}}$ & $\mathrm{D}(\AA)^{\mathrm{c}}$ \\
\hline 1 & MCM-41 & 1023 & 1.11 & 33 \\
\hline 2 & M-Sorb & 9 & 0.04 & $-^{\mathrm{d}}$ \\
\hline 3 & M-HCl & 281 & 0.22 & 25 \\
\hline 4 & $\mathrm{M}-\mathrm{HNO}_{3}$ & 283 & 0.22 & 25 \\
\hline 5 & $\mathrm{M}-\mathrm{H}_{2} \mathrm{SO}_{4}$ & 287 & 0.23 & 25 \\
\hline 6 & $\mathrm{M}-\mathrm{H}_{2} \mathrm{O}$ & 202 & 0.34 & 19 \\
\hline 7 & M-NH 3aq $_{\text {aq }}$ & 237 & 0.40 & $-^{\mathrm{d}}$ \\
\hline
\end{tabular}

${ }^{(a)}$ BET surface area;

${ }^{(b)} \mathrm{BJH}$ adsorption po revolume;

(c) Pore size is the pore diameter at which pore volume has maximum value in $\mathrm{BJH}$ adsorption $\mathrm{dV} / \mathrm{dD}$ curve;

${ }^{(d)}$ Pore volume has no maximum value in $\mathrm{BJH}$ adsorption $\mathrm{dV} / \mathrm{dD}$ curve.

$2960 \mathrm{~cm}^{-1}$ corresponds to $v(\mathrm{C}-\mathrm{H})$ stretching vibrations; $1400-1600 \mathrm{~cm}^{-1}$ being $v(\mathrm{C}-\mathrm{C})$ ring stretching vibrations; and $570-710 \mathrm{~cm}^{-1}$ being weak $v(\mathrm{C}-\mathrm{S})$ stretching vibrations (Fig. 2). The above indicated absorption bands in the spectra after grafting evidence the modifier integration into the pore structure of the MCM-41 matrix and correspond to the thiophenol groups. The treatment of samples under the conditions used do not affect on the graft layer of the sulfide sorbent.

The functional grafting content was determined by thermal analysis (TA). The curves of the weight loss for the samples obtained are given in Fig. 3. Two main processes are presented on the thermogram: the loss of the adsorbed water and organic component. Since the removal of the oxidation products from the pores is associated with diffusive difficulties, the decomposition 

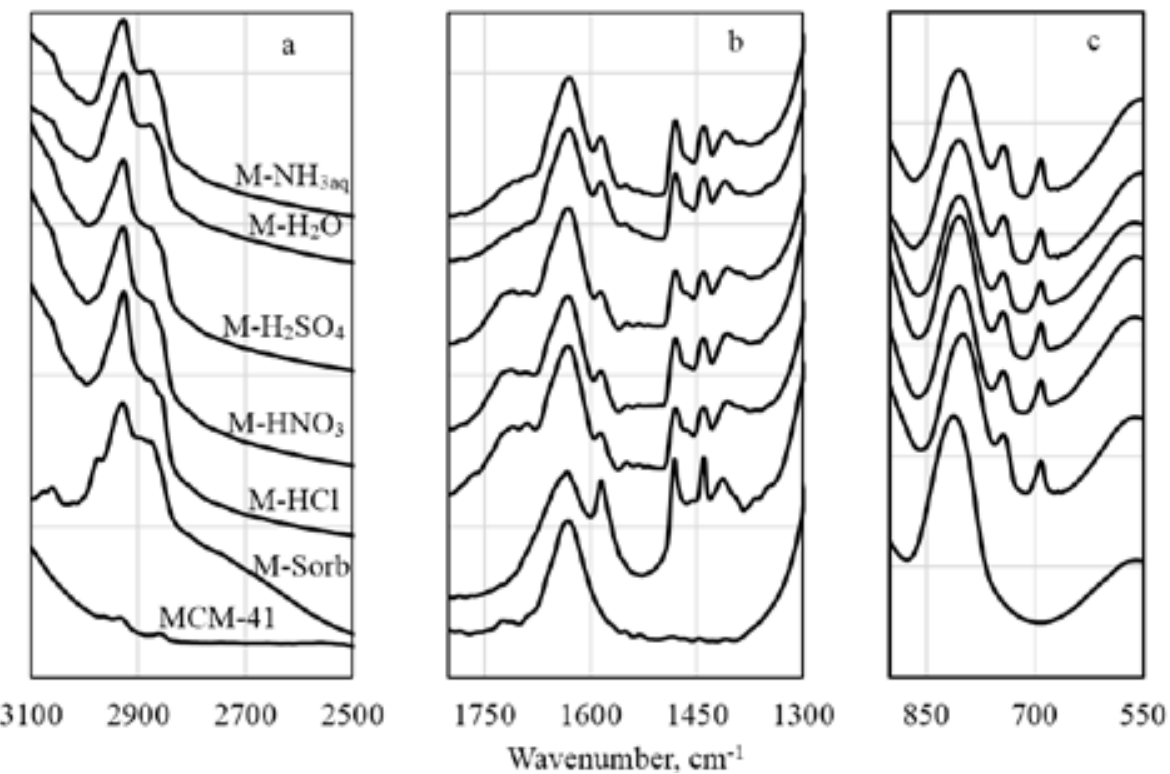

Fig. 2. Infrared spectra of MCM-41 sorbent samples after treatment: a - area $2500-3100 \mathrm{~cm}^{-1}, \mathrm{~b}-$ area 1300 $1800 \mathrm{~cm}^{-1}, \mathrm{c}$ - area $550-900 \mathrm{~cm}^{-1}$.

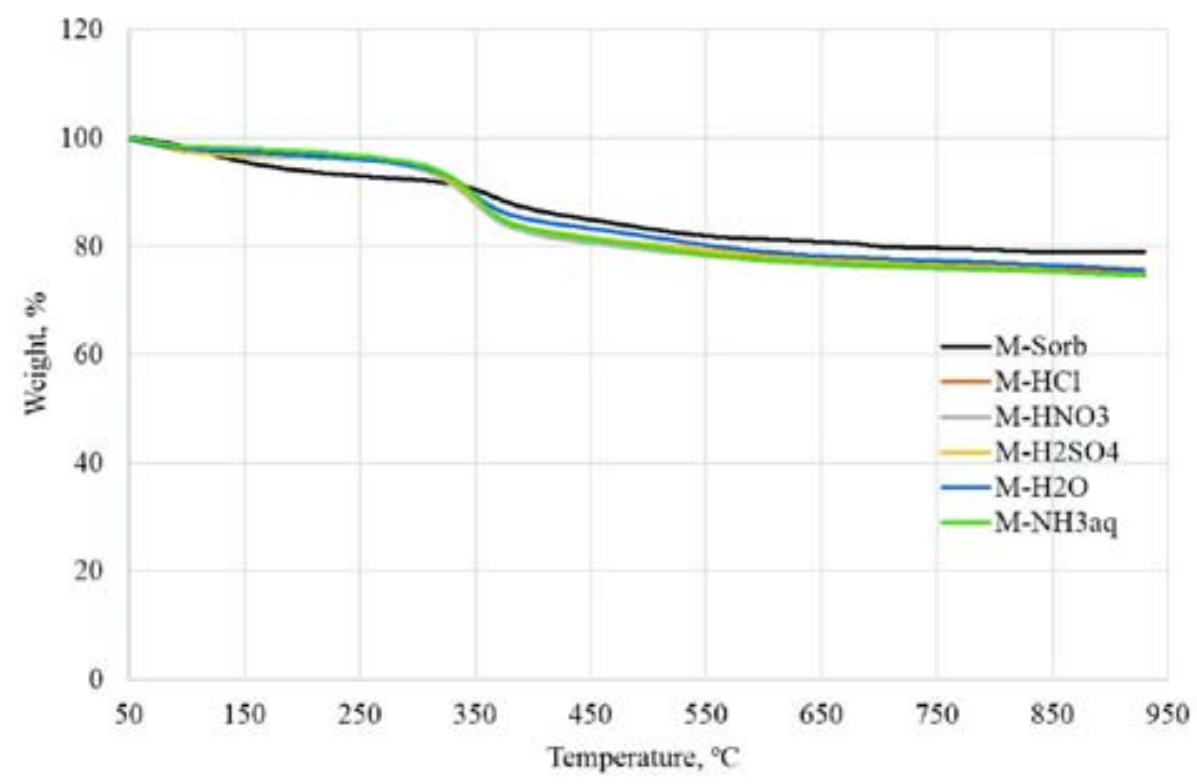

Fig. 3. Thermogram of the MCM-41 sorbent samples

is time-expanded. After the sample treatment the sample behaviour is almost identical, but the organic content is increased according to the TA data (Table 3). The increasing organic content is apparently connected with the decrease of the silica part in the samples after the treatment, which is confirmed by the XRF data. The sulfur content in the initial sorbent (the M-Sorb sample) is $0.86 \mathrm{mmol}$ per gram, but after the treatment it increases up to $1.16 \mathrm{mmol} / \mathrm{g}$ in the case of the 
Table 3. The influencing a various treatment on grafted group content and sorption capacity for MCM-41 sorbent samples

\begin{tabular}{|c|c|c|c|c|c|}
\hline Sample & $\begin{array}{c}\text { Organic content } \\
\text { by TA, wt } \%\end{array}$ & $\begin{array}{c}\text { S content, } \\
\mathrm{mmol} / \mathrm{g}\end{array}$ & $\begin{array}{c}\text { Pd content, } \\
\mathrm{mmol} / \mathrm{g}\end{array}$ & S/Pd ratio & Pd/Cl ratio \\
\hline M-Sorb & 14 & $0.86 \pm 0.05$ & $0.63 \pm 0.02$ & 1.4 & 1.7 \\
\hline M-HCl & 22 & $0.93 \pm 0.05$ & $0.43 \pm 0.02$ & 2.1 & 1.1 \\
\hline M-HNO & 22 & $0.94 \pm 0.05$ & $0.54 \pm 0.02$ & 1.8 & 1.7 \\
\hline $\mathbf{M}_{3} \mathbf{H}_{2} \mathbf{S O}_{4}$ & 21 & $0.99 \pm 0.05$ & $0.61 \pm 0.02$ & 1.6 & 1.5 \\
\hline $\mathbf{M}_{\mathbf{2}} \mathbf{O}$ & 21 & $1.15 \pm 0.05$ & $0.63 \pm 0.02$ & 1.8 & 1.2 \\
\hline $\mathbf{M}-\mathbf{N H}_{3 a q}$ & 24 & $1.16 \pm 0.05$ & $0.66 \pm 0.02$ & 1.8 & 1.2 \\
\hline
\end{tabular}

treatment with ammonia (about $26 \%$ ). This would imply that the insignificant loss of silica after the treatment results in the sharp increase of the organic content in the sample. This fact is associated with the great difference of the molecular weight between the silica unit and the modifier molecule: about 60 gram per mol versus about 350 gram per mol, correspondingly. The sorbent treatment is accompanied by the dissolution of malformed and/or unstructured particles of the silica matrix, which is the cause of the weight loss (Table 1) and increasing organic content (Table 3) after the sorbent treatment. However, the treatment does not result in significant changes in textural and sorption characteristics, while the functional grafted layer is retained. Also, the authors [25] do not recommend using ammonia medium for the real applications of such mesoporous silica materials due their amorphous framework.

The palladium(II) sorption on the studied samples was carried out from the chloride solution. The initial palladium concentration in solution was about $0.011 \mathrm{~mol}$ per liter. According XRF data after the sorption the $\mathrm{S} / \mathrm{Pd}$ ratio is about $1.5-2$, while the $\mathrm{Pd} / \mathrm{Cl}$ ratio is about $1-1.5$ as shown in Table 3 . At the average, the value of total sorption capacity of sulfide sorbent is $0.6 \mathrm{mmol}$ per gram.

\section{Conclusion}

The sulfide sorbent based on the mesostructured mesoporous silica MCM-41 was synthesized using the grafting method. The influence of aqueous media at the boiling temperature on the stability of the sorbents based on the MCM-41 matrix functionalized with the 3-(2-hydroxy-3-phenylsulfanilpropoxy) propyltrimethoxysilane was studied for the first time. The initial samples (the matrix and its sorbent) and the treated samples were characterized by the X-ray diffraction, low-temperature nitrogen adsorption, IR-spectroscopy, thermal analysis and palladium(II) sorption. The organic content and sorption ability were controlled using X-ray fluorescence. It was found that the acidic treatment was accompanied by the dissolution of the compact malformed and/or unstructured particles of the silica matrix, demonstrating the total loss of the sorbent up to $15 \mathrm{wt} \%$. The treatment with water and ammonia induces more significant changes in the matrix associated with the starting matrix dissolution (the weight loss is about 25-30 wt\%). Nevertheless, the grafted functional layer is retained. The sorbents obtained are quite stable in the studied aggressive media and are able to function over a long period of time in a variety of technological solutions and are not inferior to the well-known commercial sorbents with functional groups. 


\section{Acknowledgements}

The authors thank Alexandra Elbakyan for the resource "Sci-Hub".

\section{References}

1. Beck J.S., Vartuli J.C., Roth W.J. et. al. A new family of mesoporous molecular sieves prepared with liquid crystal templates. J. Am. Chem. Soc. 1992. (114). P. 10834-10843.

2. Zhao D.Y., Feng J. L., Huo Q.S. et. al. Triblock copolymer syntheses of mesoporous silica with periodic 50 to 300 angstrom pores. Science 1998. (279). P. 548-552.

3. Kozlova S.A., Kirik S.D. Post-synthetic activation of silanol covering in the mesostructured silicate materials MCM-41 and MCM-41. Micropor. Mesopor. Mater. 2010. (133). P. 124-133.

4. Mourabit S.E., Guillot M., Toquer G. et. al. Stability of mesoporous silica under acidic conditions. RSC Advances 2012. (2). P. 10916-10924.

5. Pérez L.L., van Eck E.R.H., Melián-Cabrera I. On the hydrothermal stability of MCM-41. Evidence of capillary tension-induced effects. Micropor. Mesopor. Mater. 2016. (220). P. 88-98.

6. Mingjuan S., Chenglong Z., Guoxing N. et. al. Improving the hydrothermal stability of mesoporous silica SBA-15 by pre-treatment with $\left(\mathrm{NH}_{4}\right)_{2} \mathrm{SiF}_{6}$. Chinese journal of catalysis 2012. Vol. 33(1). P. 140-151.

7. Kim J.M., Ryoo R. Disintegration of mesoporous structures of MCM-41 and MCM-48 in water. Bull. Korean Chem. Soc. 1996. (17). P. 66-68.

8. Zhao X.S., Audsley F., Lu G.Q. Irreversible Change of Pore Structure of MCM-41 upon Hydration at Room Temperature. J. Phys. Chem. B. 1998. (102). P. 4143-4146.

9. Haresh M. Mody, S. Kannan, H. C. Bajaj et. al. A simple room temperature synthesis of MCM-41 with enhanced thermal and hydrothermal stability. J. Porous Mater. 2008. (15) P. 571-579.

10. Cassiers K., Linssen T., M. Mathieu et al. A Detailed Study of Thermal, Hydrothermal, and Mechanical Stabilities of a Wide Range of Surfactant Assembled Mesoporous Silicas. Chem. Mater. 2002. (14). P. 2317-2324.

11. Khodakov A.Y., Zholobenko V.L., Bechara R. et al. Impact of aqueous impregnation on the long-range ordering and mesoporous structure of cobalt containing MCM-41 and SBA-15 materials. Micropor. Mesopor. Mater. 2005. (79). P. 29-39.

12. Das D., Tsai C.-M. and Cheng S. Improvement of hydrothermal stability of mesoporous molecular sieves of MCM-41 type. Studies in Surface Science and Catalysis 2000. (129). P. 85-92.

13. Koyano K.A., Tatsumi T., Tanaka Y. et al. Stabilization of mesoporous molecular sieves by trimethylsilylation. J. Phys. Chem. B. 1997. (101). P. 9436-9440.

14. Zhao X.S., Lu G.Q. Modification of MCM-41 by Surface Silylation with Trimethylchlorosilane and Adsorption Study. Phys. Chem. B. 1998. (102). P. 1556-1561.

15. Zhao D., Feng J., Huo Q. et al. Triblock copolymer syntheses of mesoporous silica with periodic 50 to 300 angstrom pores. Science 1998. (279). P. 548-552.

16. Ryoo R., Jun S. Improvement of hydrothermal stability of MCM-41 using salt effects during the crystallization process. J. Phys. Chem. B. 1997. (101). P. 317-320.

17. Yu J., Shi J.L., Chen H.R. et al. Effect of inorganic salt addition during synthesis on pore structure and hydrothermal stability of mesoporous silica. Micropor. Mesopor. Mater. 2001. (46). P. 153-162. 
18. Kozlova S.A., Zaitseva Yu.N. and Kirik S.D. Peculiarities of functionalization of mesostructured silicates MCM-41 and MCM-41 by a sulfide modifier. Glass Physics and Chemistry 2014. Vol. 40(1). P. 60-68.

19. Козлова С.А., Зайцева Ю.Н., Парфенов В.А. Стабильность сульфидных сорбентов на основе кремнезема в водных средах. Часть 1. Матрица SBA-15. Журнал Сибирского федерального университета 2016. T. 9(2). C. 177-187. [Kozlova S.A., Zaitseva Yu.N., Parfenov V.A. The stability of sulfide sorbents based on silica in aqueous media. Part I. SBA-15 matrix. J. Sib. Fed. Univ. Chemistry 2016. Vol. 9(2). P. 177-187 (In Russ.)].

20. Патент 2287485 РФ. Белоусов О.В., Парфенов В.А., Соловьев Л.А. и др. Способ ускоренного получения мезопористых мезоструктурированных силикатных материалов типа МСМ-41. Опубл. 20.11.2006. [Patent 2287485 RU. Belousov O.V., Parfenov V.A., Solovyov L.A. et al. A method for accelerated production of mesoporous mesostructured silicate materials of the MCM-41 type. Publ. Date 20.11.2006 (In Russ.)].

21. Patent 5446182 US. Bruening R.L., Tarbet B.J., Izatt R.M., Bradshaw J.S. Process of removing ions from solutions using a complex with sulfur-containing hydrocarbons also containing electron withdrawing groups bonded to a solid hydrophilic matrix. Publ. Date 29.08.1995.

22. Brunauer S., Emmet P.H., Teller E. Adsorption of gases in multimolecular layers. J. Am. Chem. Soc. 1938. (60). P. 309-319.

23. Barrett E.P., Joyner L.G., Halenda P.H. The determination of pore volume and area distributions in pure substances. J. Am. Soc. 1951. (73). P. 373-380.

24. Jaroniec M. and Solovyov L.A. Improvement of the Kruk-Jaroniec-Sayari method for pore size analysis of ordered silicas with cylindrical mesopores. Langmuir 2006. Vol. 22(16). P. 6757-6760.

25. Fotoohi B., Mercier L. Recovery of precious metals from ammoniacal thiosulfate solutions by hybrid mesoporous silica: 2 - A prospect of PGM adsorption. Separation and Purification Technology 2015. (149). P. 82-91. 